\title{
Start-Ups and External Equity: The Role of Entrepreneurial Experience
}

\begin{abstract}
A long-standing problem for most business start-ups is acquiring external equity during the first year of operations. In explaining the financing decisions of business start-ups, Meyer's (1984) pecking order theory serves as a logical working hypothesis. Treating the pecking order to be the resolution to an information problem about the potential profitability of a business startup, this paper analyzes the determinants of obtaining external equity. Special consideration is given to the role of entrepreneurial experience. The results suggest that entrepreneurial experience impacts the extent to which key factors affect a start-up's ability to obtain external equity.
\end{abstract}

\author{
Peter A. Zaleski \\ Professor of Economics \\ Villanova University \\ Villanova, PA 19085
}

Email: peter.zaleski@villanova.edu

Do Not Quote Without Permission

The author is grateful to the Kauffman Foundation for granting public access to the Kauffman Firm Survey. Certain data included herein are derived from the Kauffman Firm Survey release 3.1. Any opinions, findings, and conclusions or recommendations expressed in this material are those of the author(s) and do not necessarily reflect the views of the Ewing Marion Kauffman Foundation. 


\section{Introduction}

A long-standing problem for most business start-ups is the acquisition of external equity during the first year of operations. DeBaise, (2010) reports that this problem has worsened in 2010 as a result of the current recession. As the value of collateral shrinks, bank liquidity tightens, and professional investors still suffer from past losses, external equity is more difficult to obtain even for entrepreneurs with a long and successful track record. DeBaise (2010) reports that, "Funding from angel investors, or high-net-worth individuals who provide capital to young companies, fell 30\% to $\$ 9.1$ billion in the first half of 2009 compared with the same period a year earlier.” With resources being scarce and shrinking, an understanding of what determines the acquisition of external equity is essential.

In explaining the financing decisions of business start-ups, Meyer’s (1984) pecking order theory serves as a logical working hypothesis. The notion of a pecking order is that, in seeking capital, firms utilize internal funding before seeking external funding, and firms prefer incurring debt to raising outside equity. This preference ordering arises from the information asymmetry between managers and investors. Paul, Whitman and Wyper (2007) offer two reasons why the pecking order theory applies to start-ups. First, "In comparison to large firms, potential investors in small firms, and start-ups in particular, work with less historic performance data on which judgments about investments can be based.” Second, entrepreneurs are often motivated by a "be your own boss” mentality. Entrepreneurs may prefer debt to equity simply because lenders tend to be less intrusive than outside equity owners.

Yet, the pecking order has found little support in the empirical research on start-up financing. In a study of IPO firms, Helwege and Liang (1996) report that, “our results do not indicate that firms strongly avoid external financing, as the pecking order predicts. Furthermore, 
equity is not the least desirable source of financing, since it appears to dominate bank loans.” In a study of hi-tech start-ups, Hogan and Hutson (2004) find that outside equity is a preferred source of financing. In a case study of high growth firms, Paul, Whittam and Wyper concur. They find that entrepreneurs seek outside equity when those equity investors can offer some type of expertise. In addition, they find that lenders prefer collateral. Firms based on intellectual property may have more value than the value of their hard assets. As a result, firms in the hitech, high-growth knowledge sector may prefer issuing equity to debt. This line of reasoning is further refined by Vanacker and Manigart (2008) who find that low-risk, high profit businesses prefer debt financing while high-risk, low profit businesses, especially those investing in intangible assets, prefer equity financing.

This paper proposes to answer the question more deeply by utilizing the Kaufman Firm Survey (KFS). The KFS is fully described in Ballou, et al (2008). The goal of this paper is to determine which firm characteristics and entrepreneur characteristics can best explain whether a business start-up is able to override the pecking order, assuming it exists, and obtain external equity. In doing so, this paper will analyze the extent to which past entrepreneurial experience affects the importance of those characteristics. In this paper, external equity is defined as equity capital obtained from a source other than the founding entrepreneurs, their friends and their families.

\section{The Model}

If one considers the pecking order to be the resolution to an information problem about the potential profitability of a new start-up, then there may be proxies for information that 
investors consider when investing in a new start-up. Perhaps, the best simple proxy that investors use may be the experience level of the founding entrepreneur. The experience level of the founding entrepreneur of a business start-up may be classified into one of three categories. In group 1, there are start-ups founded by brand new entrepreneurs. These entrepreneurs have no prior experience running a business. In group 2, there are start-ups founded by entrepreneurs who have previous experience as entrepreneurs but not in the specific industry as the new start-up. Finally, in group 3, there are start-ups founded by entrepreneurs who have previous experience in the same industry as the new start-up.

Outside investors value the experience of the entrepreneur because it lends credibility to any information the entrepreneur might provide. Entrepreneurs tend to be optimistic about the future profitability of their new start-ups. Experience on the part of the entrepreneur serves two possible purposes. First, because of prior experience, the entrepreneur may temper her forecasts of the future. Secondly, whether the entrepreneur tempers her forecasts or not, outside investors may find the numbers more believable if they are forecasts from somebody with experience.

Aside from differences in entrepreneurial experience, there are a variety of key characteristics that an investor considers when deciding whether to invest in a new start-up. Many of these characteristics are analyzed by Cassar (2004) to determine which ones impact a firm's capital financing. In this section, we consider what those characteristics may be. This paper hypothesizes that not only do entrepreneurs differ in these characteristics across experience categories, but investors weight these characteristics differently across experience categories. These characteristics include both demographic characteristics and firm characteristics. 


\section{Firm Characteristics}

Established Location: Entrepreneurs can establish credibility by making a commitment. One such commitment is obtaining office space or work space separate from one's home. Such commitment sends a signal to investors that the entrepreneur is committed to establishing a lasting business and has confidence that the company can generate viable sales to maintain this commitment. It is hypothesized that entrepreneurs who establish a company work space outside the home are more likely to obtain external equity financing than entrepreneurs who work out of the owner's house or garage.

Providing a Product: Products are tangible. Services are intangible. An equity stake in a company that provides products represents an ownership claim on inventory and productive facilities. Should the company fail, the outside investor can recoup some or all of the investment by selling off the inventory and facilities. Service companies do not own such tangible assets. It is hypothesized that entrepreneurs who provide a product are more likely to obtain external equity financing than entrepreneurs who provide a service.

Providing a Service Too: Services represent a value-added feature for those companies that sell products. The value-added feature can create brand loyalty over time. Therefore, it is hypothesized that those product selling entrepreneurs that sell a service in addition to the product are more likely to obtain external equity financing than those entrepreneurs who only sell products without any additional service.

Competitive Advantage: A competitive advantage is described as something unique or distinctive a business provides that gives it an advantage compared to its competitors. It is 
important to note that in the KFS, the competitive advantage is self-reported by the entrepreneurs and may be biased as a result. Absent any self-reporting bias, it is hypothesized that entrepreneurs with a competitive advantage are more likely to obtain external equity financing than those entrepreneurs that do not have a competitive advantage.

Legal Barriers to Entry: Patents, trademarks and copyrights are legal means by which a firm retains monopoly rights to its product. These ensure that, should the firm be successful, the future profits will not be subject to erosion as outside competitors enter the market and drive down price and profit. It is hypothesized that entrepreneurs with legal barriers to entry are more likely to obtain external equity financing than those who do not have such barriers.

Percent of Sales to Business or Government: Having a government contract or being a business-to-business provider may signal to outside investors greater stability and future certainty than a business firm that relies on consumer demand for its sales. This signal may be appealing for outside investors. Alternatively, with greater risk comes greater rewards. Outside investors may find the stability of a government contract or business-to-business sales less enticing. As such, no hypothesis in made regarding the impact of these variables.

Employees: Start-up firms with employees have made a commitment regarding size and growth. It is hypothesized that entrepreneurs with employees are more likely to obtain external equity financing than those entrepreneurs who do not.

\section{Entrepreneur Characteristics}

Education: Educational achievement sends a signal to potential equity investors. Lack of a high school diploma may be viewed negatively by potential investors. Further, it is assumed that the impact of education is not linear. More education may be preferred to less, but not 
indefinitely. Thus, it is hypothesized that entrepreneurs with a high school diploma and beyond are more likely to obtain external equity financing than those without a high school diploma.

Demographics: Several demographic variables are collected by the KFS. These include ethnic group and gender. No a priori hypothesis is made regarding the impact of these. These variables are included in the analysis to determine if they do have an impact. Empirical analysis by Robb (2002) and by Coleman and Robb (2009) suggest that women and minorities receive significantly less external financing than white males.

\section{The Data}

The data come from the Kauffman Firm Survey. Firms were included in the analysis if they were a start-up under the legal status of LLC, Subchapter S Corporation or C Corporation. Sole proprietorships and partnerships were removed from the analysis to focus only on those firms that would potentially be seeking external equity from the onset. Further, all firms in the analysis are considered to be new independent businesses. Inherited businesses, purchased businesses, franchises, and non-profits are not included in the analysis.

The resulting sample includes 1,543 new start-ups. Of those, 860 firms were started by entrepreneurs with no prior experience as an entrepreneur, 360 firms were started by an entrepreneur with entrepreneurial experience in a different industry, and 323 firms were started by entrepreneurs with entrepreneurial experience in the same industry. For analysis purposes, the data are weighted using KFS supplied weights to account for the fact that high-technology firms were over-sampled. 
Descriptive summary statistics of the variables are presented in table 1 . Start-ups whose founding entrepreneur has previous experience are less likely than those with inexperienced entrepreneurs to work out of one’s house or garage. Start-ups whose founding entrepreneur has previous experience are more likely to be providing a product than those with inexperienced entrepreneurs. There is no significant difference across the three experience categories of the extent to which entrepreneurs report a competitive advantage; however, start-ups founded by entrepreneurs with experience are more likely than those firms whose founding entrepreneur has no entrepreneurial experience to have a legal barrier to entry such as a patent, trademark or copyright.

[Insert Table 1 about here]

Start-up firms whose founding entrepreneurs have no experience have a higher percentage of sales to the government than those with experienced entrepreneurs. This might suggest that government contracts might be a way for many inexperienced entrepreneurs to start a business. Start-ups whose founding entrepreneur has experience in the same industry have a higher percentage of sales to business than other types of start-ups. This might suggest that entrepreneurs with same industry experience benefit from the relationships and reputation necessary in business-to-business transactions.

Roughly half of all start-ups have no employees. This percent is slightly higher for those start-ups whose founding entrepreneur has no entrepreneurial experience. Demographically, entrepreneurs with experience in the same industry are significantly more likely to be male than entrepreneurs without experience or those changing industries. Entrepreneurs with experience but changing industries are more likely to be white than those in the same industry or with no 
experience. Entrepreneurs with no entrepreneurial experience are more likely to have no education beyond the high school diploma than those with any experience. Finally, the percentage of founding entrepreneurs with a doctoral or professional degree is roughly equal across the three experience categories.

\section{Analysis and Results}

The last row of Table 1 shows the impact of experience on obtaining external equity. Experience matters; yet, changing industries helps one obtain external equity while staying in the same industry does not significantly help. One possibility is that entrepreneurs who change industries are perceived as moving from one successful venture to another successful venture. The experience is viewed as an asset. For entrepreneurs staying in the same industry, the experience does not significantly help in obtaining external equity; the experience might be tainted by a concern that one is starting a new business in the same industry perhaps because the previous effort failed. Further research needs to be done to answer this question more fully.

The next step is to determine which firm and entrepreneur characteristics influence a firm's ability to raise external equity. The analysis is performed separately on each experience category to determine if the outside investors evaluate these characteristics differently based upon the entrepreneur's experience. For each experience category, the following logistic regression is estimated:

$\log [\mathrm{P} /(1-\mathrm{P})]=\beta_{0}+\Sigma \beta_{\mathrm{i}} \mathrm{X}_{\mathrm{i}}$

Where $\mathrm{P}$ = probability of obtaining external equity financing 
And the X's represent firm and entrepreneur characteristics listed in the Model section of the paper. The results of the logistic regression appear in table 2. For interpretation purposes, the coefficients are reported as $\mathrm{e}^{\beta}$ since the dependent variable is logarithmic. The interpretation of $\mathrm{e}^{\beta}$ is the impact that a one-unit increase in the independent variable has on the odds of getting external equity financing. When $\beta=0$, the variable has no impact, then $e^{\beta}=1$ implying even odds. A coefficient less than 1 implies a reduction in the odds of obtaining external equity financing. A coefficient greater than 1 implies an increase in the odds of obtaining external equity financing. The Wald statistic tests the hypothesis that $\mathrm{B}=0$, or similarly, that $\mathrm{e}^{\beta}=1$.

[insert Table 2 about here]

First, consider the results for those start-ups whose founders have no entrepreneurial experience. Working out of one's house or garage significantly reduces the odds of obtaining external finance by a factor of about three-fourths. Establishing a separate office and/or production facility signals to the marketplace that the entrepreneur views this start-up as a growing business to be taken seriously. Start-ups providing a product have a better chance of obtaining outside equity. The odds are 1.25 times greater for such firms to obtain external equity than for service oriented firms. Interestingly, providing a service in addition to a product reduces the likely of obtaining external equity. Perhaps investors are focusing on the tangible assets of a start-up and ignoring the intangible benefits that services would provide. Alternatively, investors might view the provision of services as a drain on profitability.

The self reported competitive advantage has a significant impact on obtaining outside equity. The odds of obtaining external equity are 1.74 times greater for start-ups reporting a competitive than for those that do not. Thus, external investors are placing some credence and 
value on this competitive advantage. Similarly, start-ups with a patent, trademark or copyright are three times more likely to obtain external equity than those firms that do not.

The percent of sales to the government has a very slight but significant impact on the odds of obtaining external equity financing. This is consistent with the hypothesis that a government contract might be a good way for an inexperienced entrepreneur to establish a business. Business-to-business sales have no significant impact on a start-up's odds of obtaining external equity. Start-ups with no employees, basically one-man or one-woman operations, have a significantly smaller chance of obtaining outside equity than those start-ups with employees. For start-ups without employees, the odds are reduced by a factor of .65.

Demographically, race, measured simply as white or non-white, has no impact on the odds of obtaining external equity. Education appears to not matter except that those new entrepreneurs with a doctorate or professional degree are than twice as likely to obtain external equity. Males are slightly, but significantly, more likely to obtain external equity than are females. This result is consistent with the findings of Robb (2009).

Several interesting results can be seen by comparing the coefficients across the three experience categories. First, for entrepreneurs with experience but changing industries, working out of one's house or garage becomes more important. The odds of obtaining external equity fall by a factor of .57 for this group as compared to .74 for inexperienced entrepreneurs. With respect to this signal, outside investors may be more forgiving when it comes to new entrepreneurs than to experienced entrepreneurs changing industries. For entrepreneurs staying in the same industry, this signal has no significant impact. While establishing an office or facility away from ones 
home send a signal to investors, this signal becomes unimportant for experienced entrepreneurs as investors focus on other factors instead.

The next interesting difference is that for experienced entrepreneurs changing industries, providing a product becomes more important than this it is for inexperienced entrepreneurs. The impact on the odds of obtaining external equity is almost three times higher for the experienced group than for the inexperienced group. Yet, for experienced entrepreneurs staying in the same industry, whether they provide a product is not a significant determinant of obtaining external equity.

For inexperienced entrepreneurs and those staying in the same industry, the effect of a self reported competitive advantage is about the same. Yet, for experienced entrepreneurs changing industries, having a self reported comparative advantage significantly decreases the odds of obtaining external equity. One possible explanation for this puzzling result is that outside investors might be more likely to view the competitive advantage as more closely associated with the entrepreneur's prior industry and does not see the same carryover to the new industry that the entrepreneur envisions. The results concerning barriers to entry are more intuitively appealing. For entrepreneurs without experience, the importance of having a patent, trademark or copyright is about twice that as it is for those entrepreneurs with experience.

Some interesting differences appear when one considers the impact education across the three experience categories. First, for inexperienced entrepreneurs and experienced entrepreneurs changing industries, there is no significant difference between the impact of having a high school diploma versus a college degree. For experience entrepreneurs staying in the same industry, having a high school diploma but not a college degree significantly reduces the odds of obtaining 
external equity by a factor of about one-fifth. For inexperienced entrepreneurs and those with experience but changing industries, a doctorate or professional degree significantly increases the odds of obtaining external equity. For those with experience in the same industry, a doctorate or professional degree significantly decreases the odds of obtaining external funding. This result may be industry specific. Since industry codes are not available in the data set employed, it was not possible to control for industry effects. It is possible that, after controlling for industry, these results may hold for certain industries but not for others.

The results concerning race are mixed. While race was not a significant determinant of external equity for inexperienced entrepreneurs, for experienced entrepreneurs changing industries, race appears to have a large impact in that whites are significantly more likely than non-whites to obtain external financing. Interestingly, for experienced entrepreneurs staying in the same industry, whites are significantly less likely to obtain external financing than nonwhites.

Regarding gender, for those entrepreneurs changing industries, females are significantly more likely than males to obtain external equity. For those entrepreneurs staying in the same industry, males are significantly more likely more likely than females to obtain external equity. There is no intuitively appealing rationale why this is so.

Overall, the results suggest that the start-ups founded by an experienced entrepreneur changing industries face tougher scrutiny than inexperienced entrepreneurs face in several respects. With respect to establishing a facility away from home, having employees, and providing a product, these factors are more important in determining whether an experienced entrepreneur changing industries obtains external equity than whether an inexperienced 
entrepreneur does. Having a patent, trademark or copyright, however, is twice as important for an inexperienced entrepreneur than for an experienced one.

For experienced entrepreneurs staying in the same industry, their experience helps reduce the importance of several factors that were critical for inexperienced entrepreneurs - namely, establishing an office or facility away from home and providing a product. Unlike experienced entrepreneurs changing industries, for experienced entrepreneurs staying in the same industry, a self reported competitive advantage has a significantly positive impact on obtaining external equity. One interpretation of this might be that entrepreneurs staying in the same industry may have credibility in this matter while entrepreneurs changing industries need to prove themselves all over again. The tougher scrutiny that entrepreneurs changing industries faces does pay off, however, since the rate at which this group obtains external equity is higher than for the other two groups.

\section{Conclusion}

The purpose of this paper is to shed light on those firm and entrepreneur characteristics that affect a start-up's chances of obtaining external equity controlling for the degree of experience. By doing so, the paper determines what factor may be employed to evaluate inexperienced entrepreneurs and whether those same criteria are applied to entrepreneurs with experience. Some differences do exist across experience categories. Most interestingly, the result that working out of one's home or garage becomes more important as an entrepreneur moves into another industry and less important for those entrepreneurs that stay in the same industry. Providing a product becomes more important for experienced entrepreneurs changing industries. 
Barriers to entry are more important for inexperienced entrepreneurs than for those with experience, but having a doctorate or professional degree is more important for experienced entrepreneurs changing industries than for either of the other two experience categories.

Some caveats do exist regarding the analysis and conclusions of this paper. First, this paper analyzes the final result of obtaining external equity as a reduced form equation. A structural model that evaluates separately the demand for and supply of external equity needs to be developed and estimated. Second, this paper only considers if external equity was obtained but does not measure the absolute dollar amount or the relative amount of the firm's entire capital structure. Additional data are needed regarding the firm's capital structure. Additional data are needed to control for industry effects and firm size. Despite these shortcomings, this paper contributes to our understanding of external equity and business start-ups. 


\section{References}

Ballou,J., Barton,T., DesRoches,D., Potter,F., Reedy,E.J., Robb,A. (2008). Kauffman

FirmSurvey: Results from the Baseline and First Follow-up Surveys. Kansas City, Mo:

Kauffman Foundation.

Cassar, Gavin. “The Financing of Business Start Ups.” Journal of Business Venturing 19 (Oct.

2004): 261-283. REPEC. Web.

Coleman, Susan, and Alicia Robb. “A Comparison of New Firm Financing by Gender: evidence from the Kauffman Firm Survey data.” Small Business Economics 33 (May 2009): 397-411.

DeBaise, Colleen. (2010) “Start-Ups Will Keep Struggling in 2010.” Wall Street Journal, Jan. 5, 2010,p.B1.

Helwege, Jean. and Liang, Nellie. (1996) “Is there a pecking order? Evidence from a panel of IPO firms.” Journal of Financial Economics. 40(3). 429-458.

Hogan, T. and Hutson, E. (2005) "What factors determine the use of venture capital? Evidence from the software sector.” Venture Capital: An International Journal of Entrepreneurial

Finance, 7 (3):259-28

Myers, Stewart C. (1984) “The Capital Structure Puzzle.” The Journal of Finance, Vol. 39, No. 3, Papers and Proceedings, Forty-Second Annual Meeting, American Finance Association, San 
Francisco, CA, December 28-30, 1983 (Jul., 1984), pp. 575-592

Robb, Alicia, “Entrepreneurial Performance by Women and Minorities: The Case of New

Firms.” (December 2002). Journal of Developmental Entrepreneurship, Vol. 7,No. 4, pp.383-97.

Paul, S., Whittam, G., Wyper, J. (2007), “The pecking order hypothesis: does it apply to start-up firms?”, Journal of Small Business and Enterprise Development, Vol. 14 No.1, pp.8-21.

Vanacker T, Mangiart S. (2008). "Pecking order and debt capacity considerations for highgrowth companies seeking financing.” Small Business Economics (online). 
Table 1. Summary Statistics

\begin{tabular}{|c|c|c|c|c|}
\hline & \multicolumn{3}{|c|}{ Experience Category } & \multirow[b]{3}{*}{ Total } \\
\hline & & Change & Same & \\
\hline & None & Industry & Industry & \\
\hline & Percent & Percent & Percent & Percent \\
\hline Works out of house or garage & $53.6 \%$ & $42.3 \%$ & $35.4 \%$ & $47.2 \%$ \\
\hline Provides a product & $44.3 \%$ & $52.2 \%$ & $48.2 \%$ & $46.9 \%$ \\
\hline Provides a service too & $33.9 \%$ & $37.8 \%$ & $37.0 \%$ & $35.5 \%$ \\
\hline Has a Competitive Advantage & $62.0 \%$ & $65.4 \%$ & $66.4 \%$ & $63.7 \%$ \\
\hline Has a Barrier to Entry & $5.4 \%$ & $6.2 \%$ & $7.0 \%$ & $5.9 \%$ \\
\hline Percent of Sales to Businesses (Mean) & $31.81 \%$ & $32.51 \%$ & $36.59 \%$ & $32.95 \%$ \\
\hline std. dev. & $41.35 \%$ & $41.92 \%$ & $43.64 \%$ & $42.00 \%$ \\
\hline Percent of Sales to Government (Mean) & $45.17 \%$ & $39.22 \%$ & $26.43 \%$ & $39.93 \%$ \\
\hline std. dev. & $17.209 \%$ & $15.48 \%$ & $12.43 \%$ & $15.94 \%$ \\
\hline Has zero employees & $55.1 \%$ & $48.2 \%$ & $51.7 \%$ & $52.8 \%$ \\
\hline Hispanic & $6.1 \%$ & $4.2 \%$ & $5.7 \%$ & $5.6 \%$ \\
\hline African-American & $12.4 \%$ & $10.7 \%$ & $7.1 \%$ & $10.9 \%$ \\
\hline Asian & $4.6 \%$ & $2.2 \%$ & $4.2 \%$ & $4.0 \%$ \\
\hline White & $79.2 \%$ & $87.5 \%$ & $83.9 \%$ & $82.1 \%$ \\
\hline Less than High School & $1.5 \%$ & $2.0 \%$ & $1.2 \%$ & $1.6 \%$ \\
\hline High School Diploma & $11.3 \%$ & $7.0 \%$ & $6.2 \%$ & $9.3 \%$ \\
\hline Doctorate or Professional & $6.4 \%$ & $6.1 \%$ & $6.5 \%$ & $6.3 \%$ \\
\hline Male & $71.3 \%$ & $72.1 \%$ & $86.1 \%$ & $74.6 \%$ \\
\hline \% Obtaining External Equity & $5.12 \%$ & $8.33 \%$ & $6.50 \%$ & $6.12 \%$ \\
\hline Unweighted n & 860 & 360 & 323 & 1543 \\
\hline \% Obtaining External Equity & $4.66 \%$ & $7.73 \%$ & $5.21 \%$ & $5.49 \%$ \\
\hline Weighted n & 868 & 357 & 318 & 1543 \\
\hline
\end{tabular}


Table 2. Regression results

\section{Experience Category}

\begin{tabular}{|c|c|c|c|}
\hline \multirow{3}{*}{ Works out of house or garage } & None & Change Ind. & Same Ind. \\
\hline & 0.744866 & 0.573735 & 1.034412 \\
\hline & $(9.371)^{*}$ & $(14.083)^{*}$ & $(0.0443)$ \\
\hline \multirow[t]{2}{*}{ Provides a service too } & 0.761588 & 0.916777 & 0.718105 \\
\hline & (3.162) & $(0.342)$ & $(2.051)$ \\
\hline \multirow[t]{2}{*}{ Provides a product } & 1.259897 & 3.057362 & 1.095604 \\
\hline & (2.397) & $(46.817)^{*}$ & $(0.177)$ \\
\hline \multirow[t]{2}{*}{ Has a Competitive Advantage } & 1.738323 & 0.390141 & 1.817424 \\
\hline & $(28.718)^{*}$ & $(49.945)^{*}$ & $(12.381)^{*}$ \\
\hline \multirow[t]{2}{*}{ Has a Barrier to Entry } & 2.908595 & 1.570803 & 1.743153 \\
\hline & $(64.445)^{*}$ & (5.163) & (6.408) \\
\hline \multirow[t]{2}{*}{ Percent of Sales to Businesses } & 0.999383 & 0.991095 & 0.994185 \\
\hline & $(0.288)$ & $(28.484)^{*}$ & $(10.988)^{*}$ \\
\hline \multirow[t]{2}{*}{ Percent of Sales to Government } & 1.004454 & 0.999038 & 0.926118 \\
\hline & (4.691) & $(0.066)$ & $(6.546)$ \\
\hline \multirow[t]{2}{*}{ Has zero employees } & 0.654171 & 0.294537 & 0.580797 \\
\hline & $(20.278)^{*}$ & $(76.860)^{*}$ & $(13.043)^{*}$ \\
\hline \multirow[t]{2}{*}{ White } & 0.94623 & 36.79182 & 0.551062 \\
\hline & $(0.261)$ & $(20.347)^{*}$ & $(11.621)^{*}$ \\
\hline \multirow[t]{2}{*}{ Less than High School } & 1.62E-08 & 2.71E-09 & 8.41E-09 \\
\hline & (3.77E-05) & $(2.45 \mathrm{E}-05)$ & $(1.12 \mathrm{E}-05)$ \\
\hline \multirow[t]{2}{*}{ High School Diploma } & 0.936088 & 0.758567 & 0.225088 \\
\hline & $(0.167)$ & (1.405) & (6.405) \\
\hline \multirow[t]{2}{*}{ Doctorate or Professional } & 2.291293 & 4.631321 & 0.137422 \\
\hline & $(37.150)^{*}$ & $(68.560)^{*}$ & $(8.024)^{*}$ \\
\hline \multirow[t]{2}{*}{ Male } & 1.206826 & 0.515317 & 1.894863 \\
\hline & (3.250) & $(24.821)^{*}$ & $(6.637) *$ \\
\hline \multirow[t]{2}{*}{ Constant } & 0.036227 & 0.007839 & 0.063865 \\
\hline & $(407.227)^{*}$ & $(36.139)^{*}$ & $(79.864)^{*}$ \\
\hline pseudo $\mathrm{R}^{2}$ & .06 & .23 & .08 \\
\hline
\end{tabular}

Wald statistic is in ( )

* significant at .01 